Article

\title{
Can Political Connections Maintain the Sustainability of R\&D Investment in China? There Is No Such Thing as a Free Lunch
}

\author{
Langzi Chen ${ }^{1}$, Jian $\mathrm{Li}^{2, *}$ and Peter Zander ${ }^{3}$ \\ 1 Management School of Nanjing Forest Police College, No. 28, Wenlan Road, Qixia District, \\ Nanjing 210046, China; chenlz@nfpc.edu.cn \\ 2 School of Business, Nan Jing Normal University, No. 1, Wenyuan Road, Qixia District, \\ Nanjing 210023, China \\ 3 Institute of Socio-Economics of Leibniz Centre for Agricultural Landscape Research, Eberswalder Str. 84, \\ 15374 Müncheberg, Germany; Peter.Zander@zalf.de \\ * Correspondence: 54176@njnu.edu.cn
}

Received: 21 October 2018; Accepted: 13 November 2018; Published: 16 November 2018

\begin{abstract}
Combining resource-based theory and social exchange theory, this paper studies the role that political connections play in maintaining the sustainability of enterprises' $R \& D$ investment. Furthermore, this paper discusses the moderating effect of policy burdens and ownership on political connections and R\&D investment. Based on the Euler equation model, this study used dynamic panel data from Chinese listed companies over the period 2006-2015 to test the hypothesis. The results show that the sustainability of R\&D investments of enterprises are more likely to face the threat of financing constraints. However, political connections can help maintain the sustainability of R\&D investment of enterprises, but this effect exists only at the local political level, and firms need to undertake a policy burden in return. Additionally, this effect is more effective in private enterprises than non-private enterprises.
\end{abstract}

Keywords: political connections; sustainability of R\&D investment; policy burden; ownership

\section{Introduction}

Under the same investment quota, uninterrupted long-term R\&D investment can avoid the high adjustment cost caused by sudden interruptions [1,2], producing better results than innovation modes that rely on short-term accumulations. Therefore, it is critical to maintain the sustainability of enterprises' R\&D investment.

Unlike substantial investment, R\&D investment typically provides incomplete information to investors concerning innovations; either this information is kept secret by the company for as long as possible, or it is difficult to depict with certainty. It is difficult for outside investors to supervise and measure the performance of $R \& D$ and the process of innovation. Hence, the R\&D investment of a firm is usually financially constrained-even in developed countries [2-8]. The ratio of direct financing to indirect financing in China is unreasonable. Direct financing means that companies can get funding from the stock market and the bond market. The proportion of direct financing to indirect financing in China was only about $15 \%$ in 2017. This proportion is much lower than the proportion of more than $50 \%$ in developed countries. Thus, it is difficult for enterprises to obtain investment funds for tangible and intangible assets in China's capital market. Due to the underdevelopment of the Chinese capital market, Chinese firms' R\&D investments are likely to suffer from significant asymmetric information problems [9]. Financing constraints have been one of the serious barriers to ensure the sustainability of R\&D investment in China [10]. 
Firms will rely more on the internal funds that come from operation activity to invest in $R \& D[2,4,5,8,9]$; this is especially true of young firms [4] and high R\&D firms [11,12].

However, Figure 1 shows that the share of total profits in GDP for Chinese industrial firms declined during 2011-2015, indicating that cash flow from profits has weakened. Simultaneously, firms' R\&D investment continued increasing steadily, regardless of the size of the firm. (These data came from the Chinese Science and Technology Statistical Yearbook, which is jointly edited by the National Bureau of Statistics and the Ministry of Science and Technology. In 2011, the statistics range of included industrial enterprises changed from industrial enterprises with sales revenue above 5 million RMB to industrial enterprises with sales revenue above 20 million RMB. To maintain uniform standards, we only used data after 2011.Additionally, since 2011, the statistical yearbook has reported not only on the overall data but also on large and medium enterprises separately, which made it feasible for us to calculate the data for small industrial enterprises by hand. By adding the data from small and medium sized enterprises, we obtained the total amount of R\&D expenditures for SMEs. Hence, Figure 1 starts from 2011.)

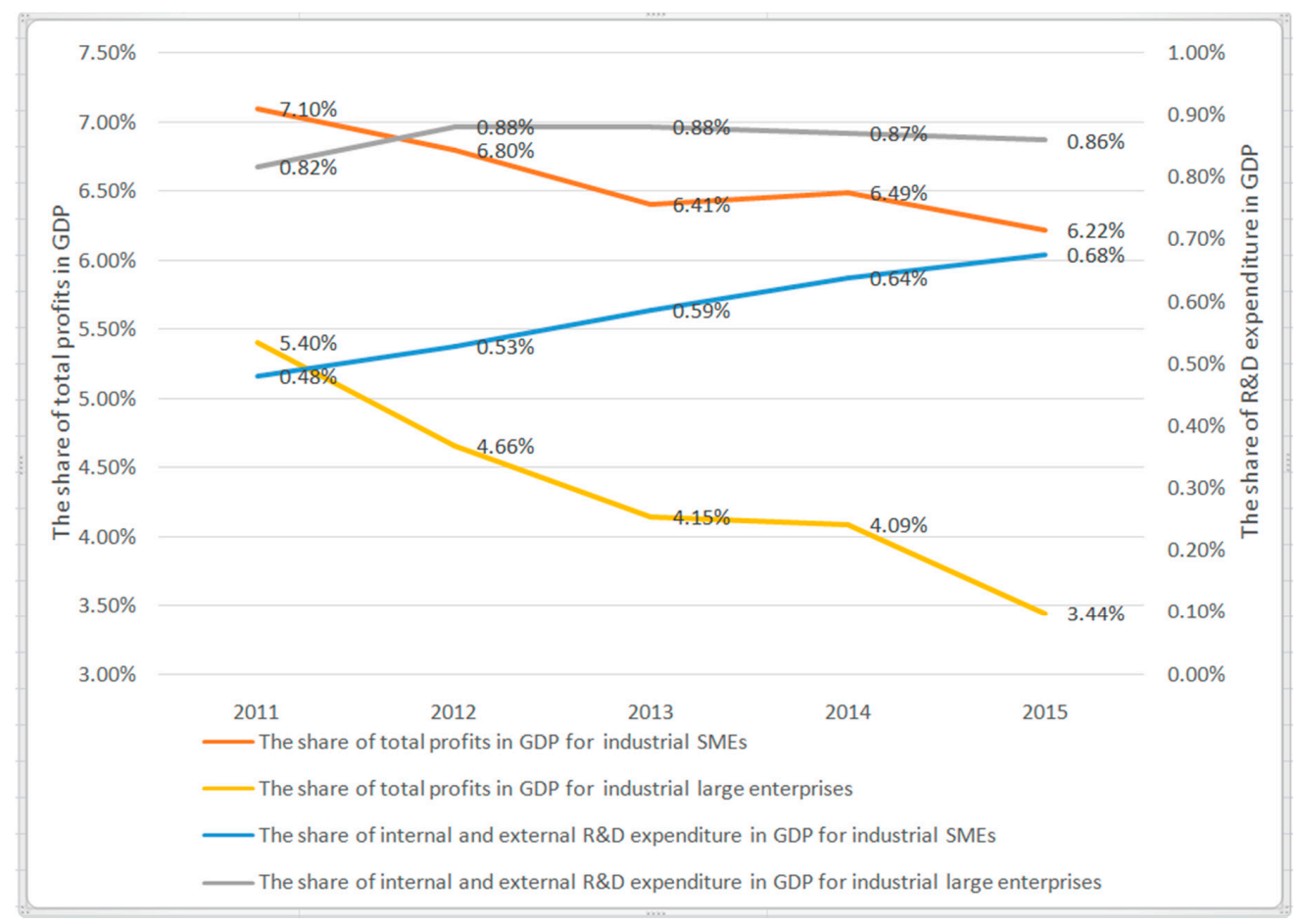

Figure 1. Trends of the share of investment expenditure in GDP for Chinese industrial firms Therefore, facing cash flow from profits declining and external financing constraints, what factors maintain the sustainability of R\&D investment of enterprises in China?

This study collected data from Chinese listed companies between 2006 and 2015 and analyzed the relationship between political connections and R\&D investment based on the Euler equation model developed by Laeven [1]. The Euler equation estimation approach eliminates terms in the solution to the optimization problem that depend on unobservable expectations such as the shadow value of capital, replacing expected values of observable variables with actual values plus an error orthogonal to predetermined instruments [4]. This approach has been widely used in the study of $R \& D$ investment and financing constraints $[4,5,8]$. We estimated the equations with the system GMM estimator [13-15].The results reveal the following: a firm-level financial constraint of R\&D investment in China was found using cash-flow analysis; as one alternative informal institutional mechanism, political connections can ease the financial constraints of firm R\&D investment and ensure the sustainability of R\&D investment, but this mechanism only exists for the political connections at 
the local level rather than the central government level. In addition, based on social exchange theory, firms need to bear a policy burden in exchange for making use of this mechanism. The above findings are more significant in private firms.

This paper makes the following main contributions based on existing studies.

First, this paper adds a new factor that can affect sustainable R\&D investment. Existing studies about sustainable R\&D investment have explored several factors that can help maintain the sustainability of $R \& D$ investment in the context of financing constraints, including cash savings [4,5], debt reduction in both the short and long run [16], equity financing [4-6,17], corporate tax reform [10,18,19], FDI [20,21], venture capital [22,23], fixed asset sales and working capital management [24,25]. Allen et al. [26] noted that the Chinese economy relies more on the development of informal factors [27-32]. Based on this point of view, this study chose political connections as a new perspective to study and confirmed that this is a new factor that can maintain the sustainability of $R \& D$ investment in China. Second, this paper adds new evidence from developing countries. Existing studies about sustainable R\&D investment in the context of financial constraints are primarily based on developed countries such as Germany [33], America [4,7,34], Ireland [35], a group of 16 countries in Europe [6] and Japan [8], all of which have mature capital markets. The number of studies in developing countries is still small $[1,10,13,25]$. In countries such as China, in which both high-speed economic growth and an imperfect financial environment exist, the poor financial environment and the stable investment of firms are in stark contrast. This contrast attracts many researchers who aim to analyze the informal financial system and its effect on firms' investment. Therefore, this paper increases the research into developing countries, which can be compared with or offer verification for the relevant research in developed countries.

Third, this paper further adds the conditions for exerting political connections. Based on social exchange theory, this study concludes that, when we discuss the effect of political connections helping to maintain the sustainability of R\&D investment, we should consider the cost of political connections. Additionally, the above finding is more significant in private firms.

\section{Theory and Hypothesis}

Political connections are important sources through which Chinese firms obtain institutional resources. Therefore, political connections in China can function as capital. Social exchange theory holds that, regardless of whether the equivalent direct resource exchange in Western society or the roundabout indirect exchange in Eastern societies such as China is used, social exchange always plays an indispensable role in maintaining social bonds and making those social bonds effective. The social exchange of political connections is commonly presented as a kind of implicit contractual relationship [36]. In the process of social exchange, government officials tend to provide connected firms with some institutional resources and protection. Obviously, the governments will want the connected firms to offer something in return. In fact, to maintain and develop its relationship with the government, the firm needs to satisfy the governments' expectations in implicit contracts [36]. Therefore, the cost of political connections must be considered when discussing the effect of those connections.

The resource-based theory provides a basis for the study of the easing mechanism from the perspective of political connections. Meanwhile, social exchange theory provides an explanation for the motivational choice and behavioral choice between the governments and firms by emphasizing the principle of mutual benefit.

\subsection{Political Connections and Sustainability of RED Investment}

Political connections can function as a reputation. A firm can have an intimate connection with the government in many ways. For example, this connection can be built by electing the corporate executives to be the deputies in the National People's Congress. This type of connection to the government can convey a signal to other firms and the public that the firm is regarded as excellent 
by the government. The problem of asymmetric information can be reduced and confidence in R\&D investment can be boosted. Second, political connections have a positive effect on reducing the operating risk of the firms. Political connections can help firms avoid rent-seeking behavior and the appropriation of private property rights by the government. Moreover, political connections can also help the firms resolve economic disputes with other firms and creditors. By taking advantage of political connections, firms can reduce the unknown market risk in the commercialization of innovation activities, boosting outside investors' confidence in R\&D investments and easing external financial constraints. Finally, in the context of the backward development of the financial market and the low efficiency of allocation, political connections help firms reduce the cost of acquiring the external financing through government help in influencing the interest rate and the loan time of banks.

Thus, this paper holds that political connections have a positive effect on easing the financial constraints of R\&D investment and puts forward the following hypothesis:

Hypothesis 1a (H1a). Political connections can ease the financial constraints and maintain the sustainability of RED investment.

China's 1994 tax-sharing reform (The State Council promulgated "Decision on the implementation of Tax-sharing financial management system" in 15 December 1993 and put it into effect on 1 January 1994) not only allowed local governments to make more decisions on economic development but also changed the financial income and distribution pattern between the central government and the local governments. According to a report released by the World Bank in 2001, fiscal decentralization made the ratio of local financial revenue to national financial revenue decline from over $70 \%$ to below $50 \%$. However, Chinese local governments undertook $70 \%$ of the public financial expenditure, and the governments below the provincial level undertook $55 \%$ of it. The imbalance in the allocation of revenue and the expenditure results in the mismatch between local governments' revenues and expenditures and the tax-sharing reform ultimately exacerbated local governments' fiscal deficit. Moreover, the promotion criteria for local government officials were also adjusted. To assess political achievements more scientifically, the central government gradually moved toward using measurable indexes to assess the political achievements of local government officials. Because of its measurability, GDP had become a commonly used index through which the central government could assess the political achievements of local government officials. Thus, competition among the local government officials gradually developed into the competition of the GDP [37]. Based on this, local governments often help firms acquire credit financing to address interlocal tax competition and to relieve the political promotion pressure caused by the application of the GDP in the assessment of political achievement. Additionally, considering that the general election of the government may cause a fluctuation infirm financing, the credit financing mentioned above is more likely to be long-term debt financing [38]. Obviously, the longer the debt maturity structure is, the more significant the easing effect on R\&D investment will be.

As the initiator of the reform of the economic system in China, the central government always adheres to the policy that the government should reduce interventions and encourage the market to guide the firms alone. As a policy maker and executor, the central government seldom provides firms with financial support. In addition, firms that have political connections with the central government are normally leading firms. These firms have advantages in scale and competitiveness and normally have strong cash flows and profitability. These advantages enable leading firms to provide R\&D investment through their own sufficient funds. In this type of case, considering the cost of the political connections, these firms are less likely to ease the financial constraints of R\&D investment by taking advantage of their central political connections.

Thus, considering internal capital reserve of a firm and the "cost" of its political connections, although political connections can help to weaken the effect of external financing on restricting the $R \& D$ investment from the perspective of the capital function of the political connection, this easing 
effect is different at different levels of political connection. Therefore, this paper puts forward the following hypothesis:

Hypothesis $\mathbf{1 b} \mathbf{( H 1 b )}$. Political connections, which can help to maintain the sustainability of RED investment, refers to local political connections but not to central political connections.

\subsection{Moderating Effect of the Policy Burden}

Influenced by traditional catching-up strategy, governments often encourage firms to invest their money in capital-intensive industries in which the firms might not have a comparative advantage. This is the origin of policy burden [39]. In the context of decentralization and economic transition, government officials tend to make connected firms undertake policy burdens while supporting them to increase GDP and obtain a political promotion. This behavior is considered by academics to be one of the ways the government depredates the resources of firms. However, from the perspective of social exchange theory, the policy burden is precisely one of the inevitable costs of political connections. Only by undertaking this burden can firms obtain institutional resources through political connections. Using social exchange theory, this paper holds the view that, while discussing the easing effect of political connections, we should also focus on the policy burden undertaken by the firms as one moderator.

In the context of economic transition, the leading role that governments play in the allocation of resources establishes the dependence of firms on the governments when acquiring resources. However, with the formulation and implementation of economic assessment standards by the central government, government departments tend to have realistic expectations and demands for firms that have political connections due to the dual pressures of tax competition and political promotion. From the above, since both the firms and the governments have resources that the other finds scarce, a one-way dependency relationship has been developed in the interdependent relationship. The local government and its departments take responsibility of promoting economic development, increasing the tax revenue and maintaining the social stability. Moreover, based on the dual pressures of tax competition and political promotion, as agents of the central government, local government departments undertake more responsibility and mission; they have stronger motives and demands in promoting local economic development. Therefore, local governments not only play a role in easing the fluctuation of R\&D investment but also interfere with the investment decision-making behavior of the firms by, for example, expanding the scale of investment or increasing the number of employees to achieve GDP growth and social stability. These interventions will ultimately enable local governments to obtain good rankings in political competitions. In summary, political connections are a double-edged sword that can provide firms with critical institutional resources, thus relieving external financial constraints and easing the fluctuation of R\&D investment; however, they also need the firms to pay for those resources by undertaking some type of policy burden. Based on Hypothesis 1, this paper puts forward the following hypothesis:

Hypothesis 2 (H2). When a firm uses local political connections to maintain the sustainability of RED investment, the firm also needs to undertake a policy burden.

\subsection{Moderating Effect of the Ownership}

At present, China is still in the midst of its economic transition. Laws and regulations are still imperfect, and financial development lags relatively behind economic development. Thus, it is difficult for firms-especially private firms - to obtain external financial for R\&D investment. This is due to three factors. First, in addition to market risks, private firms are faced with more property rights infringements, patent disputes and other risks in the process of economic transition. Compared with non-private firms, ownership is a natural weakness for private firms. When faced with an R\&D 
investment, which has a higher risk and a longer investment horizon, these firms are more likely to suffer discrimination due to their difference in ownership. Second, state-owned firms usually have a longer history. They are more likely to maintain long-term transaction relationships with state-owned banks, and they also have higher information transparency [40]. By contrast, the private firms in China generally have a short history, and external investors usually need to pay higher information costs during an R\&D investment. Third, state-owned firms often need to undertake a social policy burden as well as a policy burden due to those firms' natural ownership. This ownership also enables state-owned firms to more easily access institutional resources such as government support policies, bank loans, financial subsidies, etc. [39]. In addition, external investors also have good reasons to believe that state-owned firms have more support resources that will allow them to reduce the risks of long-term R\&D investment.

Therefore, compared with the state-owned firms, private firms are more likely to face financial constraints and are more dependent on the internal cash flows in the process of R\&D investment. The easing effect of political connections on the financial constraints is more important to private firms. Based on the former hypotheses, this paper puts forward three more hypotheses:

Hypothesis3a (H3a). Compared with non-private firms, private firms are more likely to face financial constraints in the process of sustainable RED investment.

Hypothesis3b (H3b). Compared with non-private firms, private firms are more dependent on the easing effect of the local political connections in the process of sustainable RED investment.

Hypothesis 3c (H3c). Compared with non-private firms, private firms need to undertake a greater policy burden when it gets help from the government for the sustainability of RED investment.

\section{Study Design}

\subsection{Measuring Financing Constraints on Sustainable RED Investment}

How to define the approach to study sustainability of R\&D investment is the key to distinguish this research from other R\&D investment research. Most scholars have agreed that research on the sustainability of R\&D investment is only reflected in the context of financing constraints. The logic is that, only when investment activities face external financing constraints, it is necessary to consider the issue of uninterrupted and sustainability of investment. Therefore, for the existing study of sustainability of R\&D investment [1-8], the scholars must use equations such as Euler equation to prove that R\&D investment being in the context of financing constraints. Therefore, we first define the measurement of financing constraints.

Since the seminal contribution by Fazzari et al. [41], the standard approach for testing for financial constraints has been to examine the cash flow sensitivity of investment [42]. However, it should be noted that the positive link between cash flow and investment within Tobin's Q equation, which was previously interpreted as an indicator of financial constraints, has been challenged by researchers in recent years. For example, a positive coefficient of cash flow may be caused by investment demand but not financial constraints [43], and the measurement error of Tobin's $Q$ may lead to unreliable estimates [44]. In addition, the application of Tobin's $Q$ is demanding on the efficiency of the capital market [45,46], which is not appropriate for developing countries.

The Euler equation is a structural model derived from the dynamic optimization of the "Euler condition" under the assumption of symmetric, quadratic adjustment costs relating the current investment to last period's investment and the marginal product of capital for imperfectly competitive firms. Compared with Tobin's $Q$ equation, the Euler equation offers several advantages. First, the critique from Kaplan and Zingales [43] has yet to be proven theoretically in a dynamic multi-period setting with investment adjustment costs [10]. Second, the Euler equation controls for the 
impact of the expectation of future profitability on current investments, and the estimated coefficients of lagged or current financial variables can be interpreted in a more straightforward manner [4]. Lastly, the Euler equation does not require any information on firms' market value or dividends [10]. Therefore, we examined R\&D sensitivity to political connections by estimating the Euler equation, which is widely used in the research of financial constraints and investment $[4-6,10,13]$.

\subsection{Empirical Model and Variables}

Following existing research [1,47], we used a dynamic investment model based of Euler equation to test the presence of financing constraints:

$$
\begin{aligned}
(\operatorname{Innov} / \mathrm{K})_{\mathrm{i}, \mathrm{t}} & =\alpha+\beta_{1}{ }^{*}(\operatorname{Innov} / \mathrm{K})_{\mathrm{i}, \mathrm{t}-1}+\beta_{2}{ }^{*}(\operatorname{Innov} / \mathrm{K}) 2_{\mathrm{i}, \mathrm{t}-1}+\beta_{3}{ }^{*}(\mathrm{Y} / \mathrm{K})_{\mathrm{i}, \mathrm{t}-1}+\beta_{4}{ }^{*}(\mathrm{CF} / \mathrm{K})_{\mathrm{i}, \mathrm{t}-1} \\
& +d_{t}+f_{i}+\varepsilon_{i, t}
\end{aligned}
$$

Innov represents the delta or difference in R\&D investment, measured by R\&D expenditures. We divide this index by K, which represents the total assets of the firm, to eliminate the impact of different sizes of firms. Y stands for the net output, which we use prime operating revenue to measure. CF stands for the cash flow, which we use net cash flow in the operating activities to measure. The subscript $i$ and $t$ represent individual and time, respectively, where $f_{i}$ refers to the individual effect, $d_{t}$ refers to the time effect and $\varepsilon_{i, t}$ refers to a random error term. We also use annual dummy variables to control annual fixed effect.

Bond and Meghir [47] held the view that, if the investment follows its optimal path, $\beta_{1}$ should be more than $1, \beta_{2}$ should be less than $-1, \beta_{3}$ should be positive, and $\beta_{4}$ should be negative. The coefficient of $\mathrm{CF}\left(\beta_{4}\right)$ can reflect the situation of financing constraints because, once that situation occurs, as stated by the "Pecking Order" theory, enterprises will use more internal funds for investment because the cost of internal financing is less than the cost of external financing. Thus, a firm is financially constrained if the coefficient of $\mathrm{CF}\left(\beta_{4}\right)$ is significantly positive [1]. This criterion was also used by Ratti et al. [48] and Chan et al. [49]. We established the regression in Equation (2) to examine Hypothesis 1a, which discusses the easing effect of political connections on R\&D investment.

$$
\begin{aligned}
(\operatorname{Innov} / \mathrm{K})_{\mathrm{i}, \mathrm{t}} & =\alpha+\beta_{1}{ }^{*}(\operatorname{Innov} / \mathrm{K})_{\mathrm{i}, \mathrm{t}-1}+\beta_{2}{ }^{*}(\operatorname{Innov} / \mathrm{K}) 2_{\mathrm{i}, \mathrm{t}-1}+\beta_{3}{ }^{*}(\mathrm{Y} / \mathrm{K})_{\mathrm{i}, \mathrm{t}-1}+\beta_{4}{ }^{*}(\mathrm{CF} / \mathrm{K})_{\mathrm{i}, \mathrm{t}-1} \\
& +\beta_{5}{ }^{*}(\mathrm{CF} / \mathrm{K})_{\mathrm{i}, \mathrm{t}-1} * \operatorname{Govern}_{i, t}+d_{t}+f_{i}+\varepsilon_{i, t}
\end{aligned}
$$

In the regression in Equation (2), the meanings of the Innov, $\mathrm{K}, \mathrm{Y}, \mathrm{CF}, f_{i}, d_{t}$ and $\varepsilon_{i, t}$ are the same as those in the regression in Equation (1), and Govern stands for political connections. This paper encodes the chairmen's political connections. (Although studies outside China often choose to encode the political connections of CEOs, Chinese researchers have found that the legal representative of the listed enterprise is its chairman of the board, and the chairman is also the entrepreneur and the critical decision maker. Researchers have also found that the chairman of the board is the actual controller of the enterprise. Therefore, it is appropriate to choose the chairman of the board as the entrepreneur in the case study of China.) When analyzing the resumes of chairmens of the board, we let Govern $=1$ if the chairman has served in the government or has served as a member of the National People's Congress or the National Committee of Chinese People's Political Consultative Conference; otherwise, we let Govern $=0$. If political connections can help relieve external financial constraints, then, according to Laeven [1], the firm will be less dependent on internal capital during the innovation, and $\beta_{5}$ will be significantly negative.

To examine Hypothesis $1 b$, the easing effect of political connections is different at different levels of political connections, and we therefore establish the regressions in Equations (3)-(5) to examine the influence caused by different levels of political connections after referring to the existing method.

$$
\begin{aligned}
(\operatorname{Innov} / \mathrm{K})_{\mathrm{i}, \mathrm{t}} & =\alpha+\beta_{1}{ }^{*}(\operatorname{Innov} / \mathrm{K})_{\mathrm{i}, \mathrm{t}-1}+\beta_{2}{ }^{*}(\operatorname{Innov} / \mathrm{K}) 2_{\mathrm{i}, \mathrm{t}-1}+\beta_{3}{ }^{*}(\mathrm{Y} / \mathrm{K})_{\mathrm{i}, \mathrm{t}-1}+\beta_{4}{ }^{*}(\mathrm{CF} / \mathrm{K})_{\mathrm{i}, \mathrm{t}-1} \\
& +\beta_{5}{ }^{*}(\mathrm{CF} / \mathrm{K})_{\mathrm{i}, \mathrm{t}-1} * \operatorname{Govern}_{i, t}+\beta_{6}{ }^{*}(\mathrm{CF} / \mathrm{K})_{\mathrm{i}, \mathrm{t}-1} * \operatorname{Loc}_{-} \operatorname{Cen}_{i, t}+d_{t}+f_{i}+\varepsilon_{i, t}
\end{aligned}
$$


Loc_Cen is the critical variable and represents the level difference of political connections. We let Loc_Cen $=1$ if the chairman has not served in the central government or served as a member of the National People's Congress or the National Committee of Chinese People's Political Consultative Conference but has served in local government or has served as a member of the Local People's Congress or the Local Committee of Chinese People's Political Consultative Conference. By contrast, we let Loc_Cen $=-1$ if the chairman has not served in local government or served as a member of the Local People's Congress or the Local Committee of Chinese People's Political Consultative Conference but has served in the central government or served as a member of the National People's Congress or the National Committee of Chinese People's Political Consultative Conference. Otherwise, we let the Loc_Cen $=0$. If $\beta_{6}$, the coefficient of Loc_Cen, is significantly greater than 0 , we can conclude that it is the local political connections and not the central political connections that help ease financial constraints; if $\beta_{6}$ is significantly smaller than 0 , we can conclude the opposite; and if the coefficient is not significant, we can conclude that the easing effect is not influenced by differing levels of political connections.(In the regression in Equation (3), the coefficient of easing effect of local political connections equals Govern + Loc_Cen, while the coefficient of easing effect of central political connections equals Govern-Loc_Cen. The difference between the two coefficients is 2*Loc_Cen. Moreover, if we leave out the Govern variable and only keep the Loc_Cen variable, the empirical results will remain unchanged.)

Based on the the regression in Equation (3), we establish the regressions in Equations (4) and (5) to do robustness tests on the different effects of political connections in different levels. Cengn indicates whether the firm has central political connections. We let Cengn $=1$ if the chairman of the board has served in the central government or served as a member of National People's Congress or National Committee of Chinese People's Political Consultative Conference. Otherwise, we let Cengn $=0$. Similarly, Locgn indicates whether the firm has local political connections. We let Locgn $=1$ if the chairman of the board has served in the local government or served as a member of Local People's Congress or Local Committee of Chinese People's Political Consultative Conference. Otherwise, we let Locgn $=0$. We expect that, if level differences of the easing effect of political connections on R\&D investment exist, $\beta_{5}$ in the regressions in Equations (4) and (5) will be significantly different.

$$
\begin{aligned}
(\operatorname{Innov} / \mathrm{K})_{\mathrm{i}, \mathrm{t}} & =\alpha+\beta_{1}{ }^{*}(\operatorname{Innov} / \mathrm{K})_{\mathrm{i}, \mathrm{t}-1}+\beta_{2}{ }^{*}(\operatorname{Innov} / \mathrm{K}) 2_{\mathrm{i}, \mathrm{t}-1}+\beta_{3}{ }^{*}(\mathrm{Y} / \mathrm{K})_{\mathrm{i}, \mathrm{t}-1}+\beta_{4}{ }^{*}(\mathrm{CF} / \mathrm{K})_{\mathrm{i}, \mathrm{t}-1} \\
& +\beta_{5}{ }^{*}(\mathrm{CF} / \mathrm{K})_{\mathrm{i}, \mathrm{t}-1} * \operatorname{Cengn} n_{i, t}+d_{t}+f_{i}+\varepsilon_{i, t} \\
(\operatorname{Innov} / \mathrm{K})_{\mathrm{i}, \mathrm{t}} & =\alpha+\beta_{1}{ }^{*}(\operatorname{Innnov} / \mathrm{K})_{\mathrm{i}, \mathrm{t}-1}+\beta_{2}{ }^{*}(\operatorname{Innov} / \mathrm{K}) 2_{\mathrm{i}, \mathrm{t}-1}+\beta_{3}{ }^{*}(\mathrm{Y} / \mathrm{K})_{\mathrm{i}, \mathrm{t}-1}+\beta_{4}{ }^{*}(\mathrm{CF} / \mathrm{K})_{\mathrm{i}, \mathrm{t}-1} \\
& +\beta_{5}{ }^{*}(\mathrm{CF} / \mathrm{K})_{\mathrm{i}, \mathrm{t}-1} * \operatorname{Locgn}_{i, t}+d_{t}+f_{i}+\varepsilon_{i, t}
\end{aligned}
$$

The policy burden of firms in China includes both a strategic policy burden and a social policy burden $[39,50]$. The strategic policy burden requires firms to invest in the capital-intensive industry pushed by government. In this case, these firms usually have more fixed assets under a certain operating income. The social policy burden refers to keeping redundant workers in order to help the government to solve employment problems and maintain social stability. We use Equation (6) to measure the optimal capital intensity (Intenc) determined by the relevant economic endowments [51]. This measurement method has been accepted widely in China.

$$
\begin{aligned}
(\text { Intenc })_{\mathrm{i}, \mathrm{t}} & =\alpha+\beta_{1}{ }^{*}(\text { Size })_{\mathrm{i}, \mathrm{t}-1}+\beta_{2}{ }^{*}(\text { Debt })_{\mathrm{i}, \mathrm{t}-1}+\beta_{3}{ }^{*}(\text { Growth })_{\mathrm{i}, \mathrm{t}-1}+\beta_{4}{ }^{*}(\text { Roa })_{\mathrm{i}, \mathrm{t}-1} \\
& +\beta_{5}{ }^{*}(\text { Capital })_{\mathrm{i}, \mathrm{t}-1}+\text { Region }+ \text { Industry }+ \text { Year }+\delta
\end{aligned}
$$

The variable Intenc represents capital intensity, measured by the ratio of net fixed assets to numbers of employees. The variable Size represents the size of the firm, measured by the natural logarithm of total assets. The variable Debt represents the asset-liability ratio, measured by the ratio of total liabilities to total assets. The variable Growth represents the growth of the firm, measured by the growth rate of operating income. Roa represents the return on assets of the firm. Capital represents the asset structure of the firm, measured by the ratio of current assets to total assets. Year represents 
an annual dummy variable, Region represents an area dummy variable, and Industry represents an industry dummy variable. Residual $\delta$ represents the difference of the actual capital intensity of the firm and the optimal capital intensity measured by the equation (6). When the value of $\delta$ is positive, reflecting that fixed assets of the firm are too high, then the firm assumes strategic policy burden. By contrast, when the value of $\delta$ is negative, reflecting that firms hire redundant employees relative to the assets needed, then the firm is assuming a social policy burden. Finally, we use the absolute value of $\delta$ as indicator of measuring the policy burden of firms (Burden).

We use the product term (Innov $/ \mathrm{K}_{\mathrm{t}-1}{ }^{*} \operatorname{Locgn}_{\mathrm{t}}{ }^{*} \mathrm{Burden}_{\mathrm{t}}$ ) in the regression in Equation (7) to test Hypothesis 2. We expect that the greater the policy burden that the firm undertakes, the more effective the easing effect of local political connections will be. (To ensure the completeness and tightness of this theory, we only report the product term, Innov $/ \mathrm{K}_{\mathrm{t}-1}{ }^{*} \operatorname{Locgn}_{\mathrm{t}}{ }^{*}$ Burden $_{\mathrm{t}}$, in the regression in Equation (7). However, according to social exchange theory, in order to make the political connections have an effect, enterprises need to undertake some responsibilities in return. This rule is also applied to general political connections and central political connections. The coefficients of the product term, Innov $/ \mathrm{K}_{\mathrm{t}-1}{ }^{*}$ Govern $\mathrm{t}^{*}$ Burden $_{\mathrm{t}}$ and Innov $/ \mathrm{K}_{\mathrm{t}-1}{ }^{*}$ Cengn ${ }_{\mathrm{t}}{ }^{*}$ Burden $_{\mathrm{t}}$, are also significant.) Therefore, $\beta_{7}$ should be significantly negative.

$$
\begin{aligned}
(\text { Innov } / \mathrm{K})_{\mathrm{i}, \mathrm{t}} & =\alpha+\beta_{1}{ }^{*}\left(\operatorname{Innov}_{\mathrm{H}} / \mathrm{K}\right)_{\mathrm{i}, \mathrm{t}-1}+\beta_{2}{ }^{*}(\operatorname{Innov} / \mathrm{K}) 2_{\mathrm{i}, \mathrm{t}-1}+\beta_{3}{ }^{*}(\mathrm{Y} / \mathrm{K})_{\mathrm{i}, \mathrm{t}-1}+\beta_{4}{ }^{*}(\mathrm{CF} / \mathrm{K})_{\mathrm{i}, \mathrm{t}-1} \\
& +\beta_{5}{ }^{*}(\mathrm{CF} / \mathrm{K})_{\mathrm{i}, \mathrm{t}-1}{ }^{*} \operatorname{Locgn}_{i, t}+\beta_{6}{ }^{*}(\mathrm{CF} / \mathrm{K})_{\mathrm{i}, \mathrm{t}-1}{ }^{*} \operatorname{Burden}_{i, t}+\beta_{7}{ }^{*}(\mathrm{CF} / \mathrm{K})_{\mathrm{i}, \mathrm{t}-1}{ }^{*} \operatorname{Locg}_{i, t}{ }^{*} \operatorname{Burden}_{i, t} \\
& +d_{t}+f_{i}+\varepsilon_{i, t}
\end{aligned}
$$

Finally, to test Hypothesis 3, we distinguish the ownership of the firm (Ownship) according to the type of the actual controller. We let Ownship $=0$ if the firm is a non-private firm, the actual controller of which will have a close relationship with the government, such as a government agency, a public institution, state-owned firm or a collective firm. We let Ownship $=1$ if the firm is a private firm, the actual controller of which may not have a close relationship with the government, such as an individual proprietorship or a foreign-funded firm. We consider that after dividing the firms into these two different groups, the regression in Equation (1), which reflects the effect of external financial constraints on R\&D investments, the regression in Equation (5), which reflects the easing effect of local political connections and the regression in Equation (7), which reflects that firms need to undertake policy burdens to ensure the easing effect of local political connections should have significant differences.

\subsection{Data Source and Data Description}

Brown et al. [4] found that the main financial channel of innovation investment for American high-tech firms is the stock market. However, the stock market is less developed in China. The stock market fluctuates too violently to provide steady funds for continuous innovation investment in China. To verify this point of view, it is necessary to choose listed companies in China as the empirical research object. The reason for this choice is that, if the financial constraints of continuous innovation investment still appear in these listed companies, we can prove that the equity market is not a valid source for continuous innovation investment.

The financial data of this article were all originally from annual reports released by listed SMEs in China and collected by the China Stock Market and Accounting Research (CSMAR) database (http://www.gtarsc.com), which is one of the most reliable sources of information about Chinese listed firms. Many famous universities and research institutions subscribe to it, and several previous studies relying on this source have been published [52]. We encode the chairman's political connections. Moreover, for those firms whose chairmen's resumes cannot be acquired from the CSMAR Database, we supplement the data from the websites of the listed firms. Compared with other industries, the manufacturing industry has a longer history and accounts for the majority of Chinese listed firms. The annual financial data for that industry are more credible than other industries. In addition, innovation is more important for the Chinese manufacturing industry to improve its industrial 
structure. Therefore, we chose listed manufacturing companies as the empirical samples and filtered the original samples according to the following criteria: (1) We only chose A-share listed companies and eliminated B-share and $\mathrm{H}$-share listed companies to prevent the impact of different regulatory environments; (2) We eliminated the sample firms whose stocks belong to ST or PT stock; (3) We eliminated the sample firms whose asset-liability ratio is more than $100 \%$, indicating that those firms are faced with the problem of insolvency; (4) We eliminated the sample firms whose ROA is less than $-50 \%$ or more than $50 \%$, which indicates that the firm's operation is abnormal. Finally, we acquired an unbalanced panel dataset with 589 sample firms and 4856 observations. All data came from Chinese listed manufacturing companies in the A-share stock market between 2006 and 2015.

Table 1 provides the results of the descriptive statistics analysis of the main variables in the model: for $R \& D$ investment (Innov/K), the minimum value is -0.274 , the maximum value is 0.394 , and the mean value is 0.006 ; and for internal cash flow $(\mathrm{CF} / \mathrm{K})$, the minimum value is -5.674 , the maximum value is 0.981 , and the mean value is 0.054 . These results show that the R\&D investment and internal cash flow are significantly different in different sample firms.

Table 1. Descriptive statistics of relevant variables.

\begin{tabular}{ccccc}
\hline Variable & Mean & Standard Deviation & Minimum & Maximum \\
\hline Innov $/ \mathrm{K}_{\mathrm{t}}$ & 0.001 & 0.005 & 0 & 0.077 \\
Innov $/ \mathrm{K}_{\mathrm{t}-1}$ & 0.001 & 0.005 & 0 & 0.071 \\
$(\mathrm{Innov} / \mathrm{K})^{2} \mathrm{t}-1$ & 0.000 & 0.000 & 0 & 0.005 \\
$\mathrm{Y} / \mathrm{K}_{\mathrm{t}-1}$ & 0.780 & 0.494 & 0.002 & 5.837 \\
$\mathrm{CF} / \mathrm{K}_{\mathrm{t}-1}$ & 0.054 & 0.156 & -5.674 & 0.981 \\
Govern & 0.364 & 0.481 & 0 & 1 \\
Loc_cen $_{\mathrm{t}}$ & 0.150 & 0.544 & -1 & 1 \\
Cengn $_{\mathrm{t}}$ & 0.130 & 0.336 & 0 & 1 \\
Locgn $_{\mathrm{t}}$ & 0.280 & 0.449 & 0 & 1 \\
Burden $_{\mathrm{t}}$ & 2.707 & 2.987 & 0 & 15.454 \\
Ownship $_{\mathrm{t}}$ & 0.292 & 0.455 & 0 & 1 \\
\hline
\end{tabular}

\section{Test, Estimation Method and Empirical Results}

\subsection{Regression Test and Estimation Method}

\subsubsection{The Unit Root Test of the Panel Data}

Owing to the possibility of spurious regression caused by time trends, we tested the stability of the time series, even though the time span for the empirical data was only 10 years. Compared with the unit root test of time series data, the unit root test of panel data can reduce the type II error more effectively and thus improve the efficiency of the test. The LLC test, the LPS test, the Fish-ADF test, the Fish-PP test and the Hadri test are commonly used in the unit root test of panel data. However, because the data we used are unbalanced panel data, only the Fish-ADF test or the Fish-PP test would be suitable for conducting a unit root test. Therefore, we used the Fish-ADF test and the Fish-PP test to do the unit root test (other variables in this study were dummy variables, so there was no need to conduct a unit root test on them). The original hypothesis of the test is that different cross-sectional data have different unit roots. The test results are shown in Table 2.

Table 2. The results of the unit root test.

\begin{tabular}{ccccccc}
\hline Variable & Innov/K $_{\mathbf{t}}$ & Innov/K $_{\mathbf{t}-\mathbf{1}}$ & (Innov/K) $_{\mathbf{t}-\mathbf{1}}$ & $\mathbf{Y} / \mathbf{K}_{\mathbf{t}-\mathbf{1}}$ & $\mathbf{C F} / \mathbf{K}_{\mathbf{t}-\mathbf{1}}$ & Burden $_{\mathbf{t}}$ \\
\hline Fish-ADF test & $-15.876^{* * *}$ & $-12.696^{* * *}$ & $-17.276^{* * *}$ & $-3.842^{* * *}$ & $-23.515^{* * *}$ & $-7.644^{* * *}$ \\
Fish-PP test & $-38.656^{* * *}$ & $-31.408^{* * *}$ & $-43.152^{* * *}$ & $-6.449^{* * *}$ & $-46.454^{* * *}$ & $-12.489^{* * *}$ \\
\hline
\end{tabular}


In Table 2, we can see that both the results of the Fish-ADF test and the results of the Fish-PP test reject the original hypothesis, which shows that all variables are stationary sequences and that it is reasonable to establish regression models to analyze the data.

\subsubsection{Treatment of the Endogeneity end Estimation Method}

We considered the possible factors that may cause endogeneity.

First, we used intangible assets to measure the dependent variable, and found that there are no missing values. Therefore, this sample can represent all the firms, and endogeneity due to selection bias does not occur. Second, the independent variable-political connection-is a dummy variable, and the distribution of entrepreneurs with different political backgrounds may not be completely random; thus, endogeneity may arise due to self-selection bias. Therefore, this study used a treatment effect model to test the possible endogenous dummy variable-political connection. Referring to early studies on factors that may affect the formation of the entrepreneurs' social capital [53], we performed a test using the maximum likelihood estimate (MLE), which is more effective than the Heckman two-stage model. (The master equation and the selection equation in the two-stage model involve the same variables. As a result, this model may cause mutual linear problems and bring the error caused by step one to step two, making the model less effective.) We also added some personal information of the chairman such as gender (gender), age (age), education background (edu), specialty (specialty) and functional background (background) into the treatment effect model. (Specifically, for education background, we let edu $=5$ if the chairman has a doctoral degree, edu $=4$ if the chairman has a master's degree, edu $=3$ if the chairman has a bachelor's degree, edu $=2$ if the chairman graduated from college, and edu = 1 otherwise; as for functional background, we let background = 1 if the chairman has worked as a salesman, background $=2$ if the chairman has worked as a financial employee, background $=3$ if the chairman has worked as R\&D staff, background $=4$ if the chairman has worked as a production manager, background $=5$ if the chairman has worked as a general manager, and background $=6$ otherwise; as for specialty, we let specialty $=1$ if the chairman has a science major, specialty $=2$ if the chairman has an engineering major, specialty $=3$ if the chairman has a humanities or social sciences major, specialty $=4$ if the chairman has an economy management majors, and specialty $=5$ otherwise; as for gender, we let gender $=1$ if the chairman is a male and gender $=0$ if the chairman is a female; and as for age, we let age equal the difference between the year of the sample and the year of the chairman's birth.) The results of the treatment effect model are shown in Table 3. The Wald test, presented in the last line of Table 3, explains whether the dummy variable Govern is an endogenous dummy variable. For the original hypothesis (rho $=0$ ), the $p$-value equals 0.6985 , which means that the original hypothesis cannot be rejected and confirms that the political connection is not an endogenous dummy variable. Two other dummy variables regarding political connection are both proved not to be endogenous dummy variables. Specifically, for the central political connection $\left(\right.$ Cengn $\left._{t}\right)$, the $p$-value equals 0.5720 in the Wald test of the treatment effect model; as for the local political connection $\left(\operatorname{Locgn}_{t}\right)$, the $p$-value equals 0.9254 in the Wald test of the treatment effect model. (Due to limited space, we do not report the results of the treatment effect model concerning these two dummy variables in this paper. If needed, we can provide them.) 
Table 3. Test results of the treatment effect model.

\begin{tabular}{cccccc}
\hline Innov/ $\mathrm{K}_{\mathbf{t}}$ & Coef & Std.Err & $\mathbf{z}$ & $p>|\mathbf{z}|$ & $\mathbf{9 5 \%}$ Confidence Interval \\
\hline${\text { Innov } / \mathrm{K}_{\mathrm{t}-1}}^{2}$ & -0.003 & 0.014 & -0.19 & 0.846 & $-0.031-0.025$ \\
$\left(\right.$ Innov $/ \mathrm{K}^{2}{ }_{\mathrm{t}-1}$ & 2.554 & 0.086 & 29.79 & 0.000 & $2.386-2.722$ \\
$\mathrm{Y} / \mathrm{K}_{\mathrm{t}-1}$ & -0.003 & 0.007 & -3.92 & 0.000 & $-0.004--0.001$ \\
$\mathrm{CF} / \mathrm{K}_{\mathrm{t}-1}$ & 0.025 & 0.004 & 7.27 & 0.000 & $0.018-0.032$ \\
$\mathrm{CF} / \mathrm{K}_{\mathrm{t}-1}{ }^{*} \mathrm{Govern}_{\mathrm{t}}-0.018$ & 0.005 & -4.08 & 0.000 & $-0.027--0.009$ \\
\hline Govern $_{\mathrm{t}}$ & Coef & Std.Err & $\mathbf{z}$ & $p>|\mathbf{z}|$ & $\mathbf{9 5 \%}$ Confidence Interval \\
gender $_{\mathrm{t}}$ & 0.568 & 0.124 & -4.57 & 0.000 & $-0.812-0.324$ \\
age & 0.033 & 0.003 & 10.75 & 0.000 & $0.027-0.038$ \\
edu & 0.047 & 0.024 & 1.92 & 0.055 & $-0.001-0.096$ \\
specialty & 0.038 & 0.022 & 1.70 & 0.000 & $0.137-0.233$ \\
background & 0.185 & 0.024 & 7.56 & 0.000 & $0.137-0.233$ \\
cons & -2.609 & 0.262 & -9.97 & 0.000 & $-3.122--2.096$ \\
/athrho & -0.016 & 0.077 & -0.21 & 0.831 & $-0.166-0.134$ \\
/lnsigma & -3.829 & 0.011 & -339.77 & 0.000 & $-3.851--3.807$ \\
rho & -0.029 & 0.077 & & & $-0.179-0.121$ \\
sigma & 0.022 & 0.000 & & & $0.021-0.022$ \\
lambda & -0.001 & 0.002 & & & $-0.004-0.003$ \\
\hline
\end{tabular}

Wald test of independent equations (rho $=0)$ : $\operatorname{chi} 2(1)=0.15$, Prob $>$ chi2 $=0.6985$.

Variables such as Innov $/ \mathrm{K}_{\mathrm{t}-1}$, (Innov $\left./ \mathrm{K}\right)^{2} \mathrm{t}-1, \mathrm{Y} / \mathrm{K}_{\mathrm{t}-1}$ and $\mathrm{CF} / \mathrm{K}_{\mathrm{t}-1}$ are all earlier than the independent variable (Innov $/ \mathrm{K}_{\mathrm{t}}$ ), which will not cause endogenous problems due to mutual causality. However, considering that the endogeneity may also arise from the policy burden in the same period, we used a second order lag value as its instrumental variable. To ensure the efficiency of the model, we used as many as three lag values of the independent variable in the model.

Finally, considering that the data in this paper are short panel data-the time span of the data $(\mathrm{T})$ is significantly smaller than the number of the sample firms (n) - we focused more on the problem of heteroscedasticity than the problem of serial correlation, which is more serious in long panel data. The GMM estimation is more suitable than 2SLS to solve the problem of heteroscedasticity. In addition, system GMM is more efficient than difference GMM in overcoming the problem of weak instrumental variables and a small sample. Accordingly, we employed system GMM to estimate the models. The software used was Stata12, and the regression order was xtdpdsys.

First, the Sargan test in the last line of Tables 4 and 5 shows that the original hypothesis (all the instrumental variables are effective) cannot be rejected at the 5\% level of significance. This illustrates the efficiency of the selected instrumental variables. Second, the second order autocorrelation test (AR(2)) of the regression in Tables 4-6 shows that only first order autocorrelation exists in the difference of the disturbance term. Finally, in the test of multi collinearity, the values of VIF in different models were all smaller than 10 , indicating that the regression models do not have a severe problem of multi collinearity. In conclusion, all the tests show that the models we established and the estimation method we selected are reasonable. 
Table 4. Empirical results.

\begin{tabular}{|c|c|c|c|c|c|c|}
\hline Explanatory Variable & Model (1) & Model (2) & Model (3) & Model (4) & Model (5) & Model (6) \\
\hline Innov $/ \mathrm{K}_{\mathrm{t}-1}$ & $\begin{array}{l}0.019 \\
(1.39)\end{array}$ & $\begin{array}{l}0.018 \\
(1.30)\end{array}$ & $\begin{array}{l}0.017 \\
(1.25)\end{array}$ & $\begin{array}{l}0.020 \\
(1.42)\end{array}$ & $\begin{array}{l}0.017 \\
(1.22)\end{array}$ & $\begin{array}{l}0.019 \\
(1.37)\end{array}$ \\
\hline$(\operatorname{Innov} / \mathrm{K})^{2} \mathrm{t}-1$ & $\begin{array}{c}2.314^{* * * *} \\
(5.33)\end{array}$ & $\begin{array}{c}2.359^{* * *} \\
(5.37)\end{array}$ & $\begin{array}{c}2.283^{* * *} \\
(5.25)\end{array}$ & $\begin{array}{c}2.255^{* * *} \\
(5.23)\end{array}$ & $\begin{array}{c}2.330^{* * *} \\
(5.36)\end{array}$ & $\begin{array}{c}2.327^{* * * *} \\
(5.45)\end{array}$ \\
\hline $\mathrm{Y} / \mathrm{K}_{\mathrm{t}-1}$ & $\begin{array}{c}-0.009^{* * *} \\
(-3.11)\end{array}$ & $\begin{array}{c}-0.009 * * * \\
(-3.13)\end{array}$ & $\begin{array}{c}-0.010^{* * *} \\
(-3.21)\end{array}$ & $\begin{array}{c}-0.010 \text { *** } \\
(-3.18)\end{array}$ & $\begin{array}{c}-0.010^{* * *} \\
(-3.16)\end{array}$ & $\begin{array}{c}-0.009 * * * \\
(-2.85)\end{array}$ \\
\hline Year dummy & $54.88^{* * *}$ & $59.17^{* * *}$ & $60.79 * * *$ & $55.68^{* * *}$ & $60.61^{* * *}$ & $62.17^{* * *}$ \\
\hline $\mathrm{CF} / \mathrm{K}_{\mathrm{t}-1}$ & $\begin{array}{c}0.011^{* *} \\
(1.98)\end{array}$ & $\begin{array}{c}0.020^{* * *} \\
(4.58)\end{array}$ & $\begin{array}{c}0.020^{* * *} \\
(4.57)\end{array}$ & $\begin{array}{l}0.009^{*} \\
(1.75)\end{array}$ & $\begin{array}{c}0.021^{* * *} \\
(4.80)\end{array}$ & $\begin{array}{c}0.021^{* * *} \\
(4.79)\end{array}$ \\
\hline $\mathrm{CF} / \mathrm{K}_{\mathrm{t}-1}{ }^{*}$ Govern $_{\mathrm{t}}$ & & $\begin{array}{c}-0.015^{* *} \\
(-2.26)\end{array}$ & $\begin{array}{l}-0.0003 \\
(-0.004)\end{array}$ & & & \\
\hline $\mathrm{CF} / \mathrm{K}_{\mathrm{t}-1}{ }^{*} \operatorname{Loc} \_c e n_{\mathrm{t}}$ & & & $\begin{array}{c}-0.017 \text { ** } \\
(-2.09) \\
\end{array}$ & & & \\
\hline $\mathrm{CF} / \mathrm{K}_{\mathrm{t}-1}{ }^{*}$ Cengn $_{\mathrm{t}}$ & & & & $\begin{array}{l}0.019 \\
(1.39)\end{array}$ & & \\
\hline $\mathrm{CF} / \mathrm{K}_{\mathrm{t}-1}{ }^{*} \operatorname{Locgn}_{\mathrm{t}}$ & & & & & $\begin{array}{c}-0.017^{* * *} \\
(-2.87)\end{array}$ & $\begin{array}{c}-0.017 \text { *** } \\
(-2.62)\end{array}$ \\
\hline $\mathrm{CF} / \mathrm{K}_{\mathrm{t}-1}{ }^{*}$ Burden $_{\mathrm{t}}$ & & & & & & $\begin{array}{l}0.001 \\
(0.06)\end{array}$ \\
\hline $\mathrm{CF} / \mathrm{K}_{\mathrm{t}-1}{ }^{*} \operatorname{Locgn}_{\mathrm{t}}{ }^{*}$ Burden $_{\mathrm{t}}$ & & & & & & $\begin{array}{c}-0.002 \text { ** } \\
(-2.39)\end{array}$ \\
\hline VIF & $1.00-1.16$ & $1.00-2.16$ & $1.01-3.71$ & $1.00-1.16$ & $1.00-2.02$ & $1.02-2.02$ \\
\hline $\mathrm{AR}(1)$ test & 0.000 & 0.000 & 0.000 & 0.000 & 0.000 & 0.000 \\
\hline $\mathrm{AR}(2)$ test & 0.598 & 0.703 & 0.620 & 0.551 & 0.667 & 0.621 \\
\hline Sargan test & 0.176 & 0.178 & 0.192 & 0.191 & 0.180 & 0.179 \\
\hline
\end{tabular}

${ }^{*} p<0.1,{ }^{* *} p<0.05,{ }^{* * *} p<0.01$. The figures in the brackets are $\mathbf{Z}$ values. The Sargan test reports the $p$-value in the overidentifying restrictions test of the instrumental variables. The $p$-values in the tests of the first order autocorrelation and the second order autocorrelation are reported in the AR(1) test and AR(2) test, respectively. The test of time dummy variable reports the value of chi2.

Table 5. The moderating effect of the ownership.

\begin{tabular}{|c|c|c|c|c|c|c|}
\hline Explanatory Variable & $\begin{array}{c}\text { Model (7) } \\
\text { Private }\end{array}$ & $\begin{array}{c}\text { Model (8) } \\
\text { Non-Private }\end{array}$ & $\begin{array}{c}\text { Model (9) } \\
\text { Private }\end{array}$ & $\begin{array}{c}\text { Model (10) } \\
\text { Non-Private }\end{array}$ & $\begin{array}{c}\text { Model (11) } \\
\text { Private }\end{array}$ & $\begin{array}{c}\text { Model (12) } \\
\text { Non-Private }\end{array}$ \\
\hline Innov $/ \mathrm{K}_{\mathrm{t}-1}$ & $\begin{array}{c}0.065^{* * *} \\
(4.59)\end{array}$ & $\begin{array}{l}-0.026 \\
(-1.42)\end{array}$ & $\begin{array}{c}0.064^{* * *} \\
(4.65)\end{array}$ & $\begin{array}{l}-0.027 \\
(-1.47)\end{array}$ & $\begin{array}{c}0.064 * * * \\
(4.30)\end{array}$ & $\begin{array}{l}-0.025 \\
(-1.37)\end{array}$ \\
\hline$(\operatorname{Innov} / \mathrm{K})^{2}{ }_{\mathrm{t}-1}$ & $\begin{array}{c}1.793 * * * \\
(5.47)\end{array}$ & $\begin{array}{c}4.174^{* * *} \\
(4.45)\end{array}$ & $\begin{array}{c}1.863^{* * *} \\
(5.94)\end{array}$ & $\begin{array}{c}4.167 * * * \\
(4.44)\end{array}$ & $\begin{array}{c}2.039 * * * \\
(9.03)\end{array}$ & $\begin{array}{c}4.185^{* * *} \\
(4.45)\end{array}$ \\
\hline $\mathrm{Y} / \mathrm{K}_{\mathrm{t}-1}$ & $\begin{array}{c}-0.021 * * * \\
(-6.74)\end{array}$ & $\begin{array}{c}-0.006 * * \\
(-2.17)\end{array}$ & $\begin{array}{c}-0.021 * * * \\
(-6.81)\end{array}$ & $\begin{array}{c}-0.006^{* *} \\
(-2.30)\end{array}$ & $\begin{array}{c}-0.017^{* * *} \\
(-5.32)\end{array}$ & $\begin{array}{c}-0.005^{* *} \\
(-1.97)\end{array}$ \\
\hline Year dummy & $58.43^{* * *}$ & $43.53 * * *$ & $63.26 * * *$ & $45.45^{* * *}$ & $58.74^{* * *}$ & $45.23^{* * *}$ \\
\hline $\mathrm{CF} / \mathrm{K}_{\mathrm{t}-1}$ & $\begin{array}{c}0.012 * * \\
(2.12)\end{array}$ & $\begin{array}{l}0.006 \\
(1.24)\end{array}$ & $\begin{array}{c}0.023^{* * *} \\
(3.25)\end{array}$ & $\begin{array}{c}0.011^{* * *} \\
(2.64)\end{array}$ & $\begin{array}{c}0.022^{* * *} \\
(3.01)\end{array}$ & $\begin{array}{c}0.011^{* * * *} \\
(2.63)\end{array}$ \\
\hline $\mathrm{CF} / \mathrm{K}_{\mathrm{t}-1}{ }^{*} \operatorname{Locgn}_{\mathrm{t}}$ & & & $\begin{array}{c}-0.019^{* *} \\
(-2.48)\end{array}$ & $\begin{array}{l}-0.009 \\
(-1.06)\end{array}$ & $\begin{array}{c}-0.024^{* * *} \\
(-2.74)\end{array}$ & $\begin{array}{l}-0.006 \\
(-0.86)\end{array}$ \\
\hline $\mathrm{CF} / \mathrm{K}_{\mathrm{t}-1} *$ Burden $_{\mathrm{t}}$ & & & & & $\begin{array}{c}-0.025^{* * *} \\
(-2.62)\end{array}$ & $\begin{array}{l}0.015 \\
(1.48)\end{array}$ \\
\hline $\mathrm{CF} / \mathrm{K}_{\mathrm{t}-1}{ }^{*} \operatorname{Locgn}_{\mathrm{t}}{ }^{*}$ Burden $_{\mathrm{t}}$ & & & & & $\begin{array}{c}-0.003^{* * *} \\
(-2.63)\end{array}$ & $\begin{array}{l}-0.001 \\
(-0.68)\end{array}$ \\
\hline VIF & $1.01-1.20$ & $1.00-1.14$ & $1.00-1.73$ & $1.00-2.16$ & $1.02-1.76$ & $1.03-2.16$ \\
\hline $\mathrm{AR}(1)$ test & 0.000 & 0.000 & 0.000 & 0.008 & 0.002 & 0.007 \\
\hline $\mathrm{AR}(2)$ test & 0.536 & 0.485 & 0.612 & 0.511 & 0.379 & 0.508 \\
\hline Sargan test & 0.456 & 0.245 & 0.412 & 0.249 & 0.358 & 0.231 \\
\hline
\end{tabular}

** $p<0.05,{ }^{* * *} p<0.01$. The figures in the brackets are $\mathrm{Z}$ values. The Sargan test reports the $p$-value in the overidentifying restrictions test of the instrumental variables. The $p$-values in the tests of first order autocorrelation and second order autocorrelation are reported in the AR(1) test and $\mathrm{AR}(2)$ test. The test of time dummy variable reports the value of chi2. 
Table 6. Results of the robustness test.

\begin{tabular}{|c|c|c|c|c|c|c|}
\hline Explanatory Variable & Model (13) & Model (14) & $\begin{array}{l}\text { Model (15) } \\
\text { Private }\end{array}$ & $\begin{array}{c}\text { Model (16) } \\
\text { Non-Private }\end{array}$ & $\begin{array}{l}\text { Model (17) } \\
\text { Private }\end{array}$ & $\begin{array}{c}\text { Model (18) } \\
\text { Non-Private }\end{array}$ \\
\hline Innov $/ \mathrm{K}_{\mathrm{t}-1}$ & $\begin{array}{l}0.017 \\
(1.23)\end{array}$ & $\begin{array}{l}0.020 \\
(1.45)\end{array}$ & $\begin{array}{c}0.064^{* * *} \\
(4.64)\end{array}$ & $\begin{array}{l}-0.026 \\
(-1.43)\end{array}$ & $\begin{array}{c}0.065^{* * *} \\
(4.36)\end{array}$ & $\begin{array}{l}-0.024 \\
(-1,34)\end{array}$ \\
\hline$(\operatorname{Innov} / \mathrm{K})^{2} \mathrm{t}-1$ & $\begin{array}{c}2.271^{* * *} \\
(5.24)\end{array}$ & $\begin{array}{c}2.301 * * * \\
(5.34)\end{array}$ & $\begin{array}{c}1.853^{* * * *} \\
(5.86)\end{array}$ & $\begin{array}{c}4.164^{* * *} \\
(4.43)\end{array}$ & $\begin{array}{c}2.062^{* * *} \\
(9.10)\end{array}$ & $\begin{array}{c}4.181^{* * *} \\
(4.45)\end{array}$ \\
\hline $\mathrm{Y} / \mathrm{K}_{\mathrm{t}-1}$ & $\begin{array}{c}-0.010^{* * *} \\
(-3.23)\end{array}$ & $\begin{array}{c}-0.010^{* *} \\
(-3.16)\end{array}$ & $\begin{array}{c}-0.021 \text { *** } \\
(-6.86)\end{array}$ & $\begin{array}{c}-0.006^{* *} \\
(-2.30)\end{array}$ & $\begin{array}{c}-0.017^{* * *} \\
(-5.31)\end{array}$ & $\begin{array}{c}-0.006^{* *} \\
(-1.99)\end{array}$ \\
\hline Year dummy & $60.61^{* * *}$ & $54.66^{* * *}$ & $63.57^{* * *}$ & $45.02 * * *$ & $57.86^{* * *}$ & $44.63^{* * *}$ \\
\hline $\mathrm{CF} / \mathrm{K}_{\mathrm{t}-1}$ & $\begin{array}{c}0.019^{* * *} \\
(4.35)\end{array}$ & $\begin{array}{l}0.010^{*} \\
(1.82)\end{array}$ & $\begin{array}{c}0.022^{* * * *} \\
(3.27)\end{array}$ & $\begin{array}{c}0.011^{* * *} \\
(2.50)\end{array}$ & $\begin{array}{c}0.019^{* * *} \\
(2.89)\end{array}$ & $\begin{array}{l}0.011^{* *} \\
(2.49)\end{array}$ \\
\hline $\mathrm{CF} / \mathrm{K}_{\mathrm{t}-1}{ }^{*} \mathrm{P}_{-}$Cengn $_{\mathrm{t}}$ & $\begin{array}{l}0.026^{*} \\
(1.72)\end{array}$ & & & & & \\
\hline $\mathrm{CF} / \mathrm{K}_{\mathrm{t}-1}{ }^{*} \mathrm{P}_{-}$Locgn $_{\mathrm{t}}$ & $\begin{array}{c}-0.015^{* * *} \\
(-2.70)\end{array}$ & & $\begin{array}{c}-0.018^{* *} \\
(-2.42)\end{array}$ & $\begin{array}{l}-0.008 \\
(-1.04)\end{array}$ & $\begin{array}{c}-0.021^{* *} \\
(-2.49)\end{array}$ & $\begin{array}{l}-0.005 \\
(-0.78)\end{array}$ \\
\hline $\mathrm{CF} / \mathrm{K}_{\mathrm{t}-1}{ }^{*} \mathrm{D}_{\text {_govern }} \mathrm{t}$ & & $\begin{array}{l}0.013 \\
(0.68)\end{array}$ & & & & \\
\hline $\mathrm{CF} / \mathrm{K}_{\mathrm{t}-1}{ }^{*}$ Burden $_{\mathrm{t}}$ & & & & & $\begin{array}{c}-0.021^{* * *} \\
(-2.42)\end{array}$ & $\begin{array}{l}0.015 \\
(1.49)\end{array}$ \\
\hline CF $/ K_{t-1}{ }^{*} P_{-}$Locgn $_{t}^{*}$ Burden $_{t}$ & & & & & $\begin{array}{c}-0.003^{* * *} \\
(-2.60)\end{array}$ & $\begin{array}{l}-0.0004 \\
(-0.62) \\
\end{array}$ \\
\hline VIF & $1.00-2.03$ & $1.00-1.16$ & $1.01-1.65$ & $1.00-2.09$ & $1.02-1.66$ & $1.03-2.09$ \\
\hline $\mathrm{AR}(1)$ test & 0.000 & 0.000 & 0.000 & 0.007 & 0.001 & 0.008 \\
\hline $\mathrm{AR}(2)$ test & 0.584 & 0.602 & 0.596 & 0.515 & 0.366 & 0.509 \\
\hline Sargan test & 0.195 & 0.184 & 0.437 & 0.243 & 0.369 & 0.226 \\
\hline
\end{tabular}

${ }^{*} p<0.1,{ }^{* *} p<0.05,{ }^{* * *} p<0.01$. The figures in the brackets are $\mathrm{Z}$ values. The Sargan test reports the $p$-value in the overidentifying restrictions test of the instrumental variables. The $p$-values in the tests of first order autocorrelation and second order autocorrelation are reported in the AR(1) test and AR(2) test, respectively. The test of the time dummy variable reports the value of chi2.

\subsection{Empirical Results}

Model (1) in Table 4 reports the empirical results of the regression in Equation (1). According to Laeven [1], if external financial constraints do not affect the firm's innovation activities, $\beta_{4}$, then the coefficient of cash flow will be smaller than 0 . However, we can see that $\beta_{4}$ in Model (1) is greater than 0 and that the $p$-value is 0.048 . This result shows that the R\&D investment of the Chinese manufacturing industry is faced with external financial constraints and that the investment-cash flow sensitivity is obvious in the innovative activities. Additionally, according to the Chinese Entrepreneur Survey System (2015), the proportion of the firms that use their own capital to invest in innovation activities increased by $6.1 \%$ from 2000 to 2014 ( $84.7 \%$ in 2000 and $90.8 \%$ in 2014), and the proportion of the firms whose innovation relies on bank loans decreased by $16.5 \%$ from 2000 to 2014 . This information verifies that, even for the listed firms, $R \& D$ investment in China is facing financial constraints. Existing studies about sustainable R\&D investment in the context of financial constraints are few based on developing countries [1,10,13]. Laeven [1] used panel data on many firms in 13 developing countries (not including China) to find out whether financial liberalization relaxes financing constraints of firms during the period 1988-1998. Howell [10] studied the relationship between firms' innovation activities, financial constraints and corporate tax in China during the period 2001-2007. Sasidharan et al. [13] studied examines the extent to which financing constraints affect the research and development (R\&D) expenditure of Indian manufacturing firms during the period 1991-2011. They all proposed that R\&D investment of enterprises in developing countries facing external financing constraints, and the research conclusion of this paper is consistent with them. Besides, the period of data used in this study is 2006-2015, which indicates that the problem of sustainable R\&D investment of enterprises in developing countries has not been eliminated with time. Model (2) in Table 4 reports the empirical results of the regression in Equation (2). The coefficient of the product term $\left(\mathrm{CF} / \mathrm{K}_{\mathrm{t}-1}{ }^{*} \mathrm{Govern}_{\mathrm{t}}\right)$ is negative, and the $p$-value is 0.024 . This result shows that for Chinese manufacturing firms, political 
connections can function as a supplement to formal institutions, which can help to relieve the external financial constraints and ensure the sustainability of $R \& D$ investment. Therefore, Hypothesis 1a is supported. Existing studies show that as an informal alternative mechanism, political connections can help firms relieve these financial constraints by acquiring critical institutional resources such as financial subsidies [27], bank loans [28], or tax preference [29]. The research conclusions of this paper support the views of these studies. It shows that political connections can help firms overcome the problems in development as an informal alternative mechanism when the market economic has not been fully established in China.

Model (3) examines the difference between the easing effect of central political connections and easing effect of local political connections. The coefficient of $\operatorname{Loc}_{-} \mathrm{Cen}_{\mathrm{t}}$ is negative, and the $p$-value is 0.036 . We can conclude that local political connections are more effective than central political connections in easing the fluctuation of R\&D investments when the firm is faced with external financial constraints. In other words, the effect of political connections lies more on local governments. Therefore, Hypothesis $1 \mathrm{~b}$ is supported. Models (4) and (5) compare the product term of central political connection and cash flow $\left(\mathrm{CF} / \mathrm{K}_{\mathrm{t}-1}{ }^{*} \mathrm{Cengn} \mathrm{n}\right)$ with the product term of local political connection and cash flow $\left(\mathrm{CF} / \mathrm{K}_{\mathrm{t}-1}{ }^{*} \operatorname{Locgn}_{\mathrm{t}}\right)$. In this comparison, we found that the coefficient of $\mathrm{CF} / \mathrm{K}_{\mathrm{t}-1}{ }^{*}{ }^{*}$ engn $\mathrm{n}_{\mathrm{t}}$ is positive and the $p$-value is 0.164 , while the coefficient of $C F / K_{t-1}{ }^{*} \operatorname{Locgn}_{t}$ is negative and the $p$-value is 0.004 . These results demonstrate that the easing effect is significantly different at different levels of political connection. This evidence supports the existence of the reciprocity principle and the rational principle of social exchange in the application of political connections; both firms and governments will consider the cost and value of political connections. These results provide a more believable explanation for the differences between the central government and local governments in intervening infirm operation. In the context of economic transition in China, a growing number of scholars have found that policies taken by local governments usually conflict with the policies taken by the central government, such as reforestation [30], healthcare policy [31], financial systems [32], etc. Based on social exchange theory, this paper continues the study of Allen et al. [26], supporting and extending the research findings discussed above.

By adding the policy burden into the product term, Model (6) reports the empirical results of the regression in Equation (7). The coefficient of CF/ $\mathrm{K}_{\mathrm{t}-1}{ }^{*} \operatorname{Locgn}_{\mathrm{t}}{ }^{*} \mathrm{Burden}_{\mathrm{t}}$ is negative, and the $p$-value is 0.017. This result shows that, although local political connections as informal institutions can help to maintain the sustainability of enterprises' R\&D investment, this effect requires the firm that benefits from the local political connections to pay a "cost". The confirmation of Hypothesis 2 also proves the reasonability of social exchange theory reflected in Hypothesis $1 \mathrm{~b}$.

Based on the analysis of the easing effect of political connections, we also discuss the moderating effect of the ownership. After dividing all the samples into two groups-private firms (1416 sample firms) and non-private firms (3340 sample firms) - we performed regression tests on these groups. The test results are shown in Table 5.

Models (7) and (8) examine the moderating effect of ownership on relationship between the $R \& D$ investment and the financial constraints. In the private firms group, the coefficient of $C F / K_{t-1}$ is positive, and the $p$-value is 0.034 . However, in the group of non-private firms, the coefficient of $\mathrm{CF} / \mathrm{K}_{\mathrm{t}-1}$ is positive, and the $p$-value is 0.216 . Therefore, compared with the non-private firms, the private firms are more likely to face financial constraints and are more dependent on internal cash flows for R\&D investment. Hypothesis 3a is supported. Howell [10] proposed that lack of access to finance is a primary constraint on Chinese innovation particularly for privately-owned enterprises in China. His research sample was the period 2001-2007. This paper supports his point of view about moderating effect of ownership using data for 2006-2016. It shows that the financing constraints problem of R\&D investment in private enterprise has not been resolved even after eight years.

Models (9) and (10) examine the difference in the effect of local political connections in different ownerships. In the group of private firms, the $p$-value of the coefficient of $C F / K_{t-1}{ }^{*} \operatorname{Locgn}_{t}$ is 0.013 . However, in the group of non-private firms, the $p$-value of the coefficient of CF/ $\mathrm{K}_{\mathrm{t}-1}{ }^{*} \operatorname{Locgn}_{\mathrm{t}}$ is 0.289 . 
Therefore, compared with non-private firms, private firms are more dependent on the easing effects of the local political connections on external financial constraints in $R \& D$ investment. Hypothesis $3 b$ is supported.

Models (11) and (12) study the policy burden that firms in different ownerships need to undertake to ensure that the easing effect of local political connections will be effective. In the group of private firms, the $p$-value of the coefficient of $\mathrm{CF} / \mathrm{K}_{\mathrm{t}-1}{ }^{*} \operatorname{Locgn}_{\mathrm{t}}{ }^{*} \mathrm{Burden}_{\mathrm{t}}$ is 0.008 . However, in the group of non-private firms, the $p$-value of the coefficient of CF/K $\mathrm{K}_{\mathrm{t}-1}{ }^{*} \operatorname{Locgn}_{\mathrm{t}}{ }^{*} \mathrm{Burden}_{\mathrm{t}}$ is 0.499 . Therefore, compared with the non-private firms, which have a natural advantage in ownership, the private firms need to undertake more policy burdens to effectively mobilize and make the use of the "capital" function of political connections, thereby making the easing effect of the political connections work. Hypothesis $3 \mathrm{c}$ is supported.

\subsection{Robustness Test}

We used another method to test the level of difference in political connections. Specifically, we set P_Locgn $=1$ if the entrepreneur has served in the local government or served as a member of the Local People's Congress or the Local Committee of Chinese People's Political Consultative Conference but has never served in the central government or served as a member of the National People's Congress or the National Committee of Chinese People's Political Consultative Conference. Otherwise, we set P_Locgn $=0$. We set P_Cengn $=1$ if the entrepreneur has served in the central government or served as a member of the National People's Congress or the National Committee of Chinese People's Political Consultative Conference but has never served in the local government or served as a member of the Local People's Congress or the Local Committee of Chinese People's Political Consultative Conference. Otherwise, we set P_Cengn $=0$. We set D_Govern $=1$ if the entrepreneur not only has central political connections but also has local political connections. Otherwise, we set D_Govern $=0$. After changing the method of measuring political connections, the results of the robustness test are shown in Table 6 .

P_Cengn in Model (13) represents the firms that only have central political connections, while the P_Locgn in Model (13) represents the firms that only have local political connections. As we can see in Table 6, Model (13) shows that only coefficient of P_Locgn is negative and the $p$-value is 0.007 . This result indicates that it is local political connections rather than central political connections that can help ease financial constraints of R\&D investment. D_Govern in Model (14) represents the firms that have both local political connections and central political connections. We assumed that, if only local political connections have an easing effect while central political connections do not, the easing effect of the political connections will be weakened when the firms have both local political connections and central political connections. The regression result shows that the $p$-value of the coefficient of D_Govern is 0.496. The empirical results of Models (13) and (14) support Hypothesis 1b.

Models (15) and (16) examine the moderating effect of different ownerships during the process using local political connections to obtain an easing effect. In the group of private firms, the $p$-value of the coefficient of $\mathrm{CF} / \mathrm{K}_{\mathrm{t}-1}{ }^{*} \mathrm{P}_{-} \mathrm{Locgn}_{\mathrm{t}}$ is 0.015 . However, in the group of non-private firms, the $p$-value of the coefficient of $\mathrm{CF} / \mathrm{K}_{\mathrm{t}-1}{ }^{*} \mathrm{P} \_\mathrm{Locgn}_{\mathrm{t}}$ is 0.299 . These results support the hypothesis that private firms are more dependent on the easing effect of local political connections than non-private firms. Models (17) and (18) examine the policy burden that firms under different ownerships need to undertake while using the local political connections to ease financial constraints of R\&D investment. The regression results show that, in the group of private firms, the $p$-value of the coefficient of $\mathrm{CF} / \mathrm{K}_{\mathrm{t}-1}{ }^{*} \mathrm{P}_{-} \operatorname{Locgn}_{\mathrm{t}}{ }^{*}$ Burden $_{\mathrm{t}}$ is 0.009 . However, in the group of non-private firms, the $p$-value of the coefficient of $\mathrm{CF} / \mathrm{K}_{\mathrm{t}-1}{ }^{*} \mathrm{P}_{-}$Locgn $_{\mathrm{t}}{ }^{*} \mathrm{Burden}_{\mathrm{t}}$ is 0.536 . Consistent with the previous conclusions, these results indicate that compared with non-private firms, undertaking policy burdens is more necessary for private firms to make the use of political connections. 


\section{Conclusions and Implications}

Innovation is the source of sustainable development of the world, and enterprise is one of the key promoters of innovation. Compared with the research institutes in government, the R\&D investment of enterprises is more likely to be interrupted due to decreasing of internal income and external financing constraints. Therefore, maintaining the sustainability of R\&D investment of enterprises should be one of the critical issues in research field of sustainability. In this study, we discuss and analyze how political connections, as a complement to informal institutions, can help ease financial constraints and maintain the sustainability of enterprises' R\&D investment during the period of Chinese economic transition. The results show that the sustainability of R\&D investment of enterprises is more likely to face the threat of financing constraints. However, political connections can help maintain the sustainability of R\&D investment of enterprises, but this effect exists only at the local political level, and firms need to undertake a policy burden in return. Additionally, this effect is more effective in private enterprises than non-private enterprises.

In this paper, the capital function of political connections is based on the resource-based theory. However, Confucianism is deeply rooted in Chinese society, making it a relation-based society. In this type of society, social bonds should be maintained via the exchange behavior even though the exchange is indirect. When studying the effect of political connection maintaining sustainability of enterprises' R\&D investment, we need to use social exchange theory to analyze the motivation and cost of political connections.

Our results indicate the following. First, even for listed firms with relatively wide financial channels, sustainability of R\&D investment of enterprises still face financial constraints. Therefore, expanding financial channels to help firms acquire long-term funding for Sustainable R\&D investment from the stock market, bond market and banks should be the Chinese government's top priority. Second, because of the imperfect institutional construction and the financial constraints on $R \& D$ investment, establishing political connections with governments to maintain the sustainability of R\&D investment becomes a rational choice for firms, especially for private firms. Therefore, to weaken the potential motivation of Chinese entrepreneurs' rent-seeking behavior, the government should accelerate the establishment of a sound formal institution, deepen economic restructuring and give full play to the market's leading role in resource allocation.

Further research can be undertaken in the following directions. First, political connections exist in many developing countries and even in developed counties. The measurement of political connections in this paper is widely used in China, and measuring political connections, such as political donations, in other countries will be interesting to explore similar results. Second, to rule out the impact of equity financing, we use listed firms; one could test whether the results also hold for unlisted firms. Third, making a distinction between "research" (R) and "development" (D) has been emphasized by some studies. However, the data from listed firms in China prevent us from doing this type of exercise. Fourth, future research can consider other forms of data to test whether there is an effect of corruption in the use of political connections.

Author Contributions: J.L. was responsible for generating the idea and writing the article. L.C. was responsible for gathering the data and performing the analyses. P.Z. was involved in providing guidance throughout the process.

Funding: This work was supported by the National Natural Science Foundation of China (71302118; 71872042), the Fundamental Research Funds for the Central Universities (RWZD201802) and the Fundamental Research Funds for the Central Universities (30917014110).

Conflicts of Interest: The authors declare no conflict of interest.

\section{References}

1. Laeven, L. Does Financial Liberalization Reduce Financing Constraints? Financ. Manag. 2003, 32, 5-34. [CrossRef]

2. Hall, B.H. The Financing of Research and Development. Oxf. Rev. Econ. Policy 2002, 18, 35-51. [CrossRef] 
3. Himmelberg, C.P.; Petersen, B.C. R\&D and Internal Finance: A Panel Study of Small Firms in High-Tech Industries. Rev. Econ. Stat. 1994, 76, 38-51.

4. Brown, J.R.; Fazzari, S.; Petersen, B.C. Financing Innovation and Growth: Cash Flow, External Equity and the 1990s R\&D Boom. J. Financ. 2009, 64, 151-185.

5. Brown, J.R.; Petersen, B.C. Why Has the Investment-Cash Flow Sensitivity Declined So Sharply? Rising R\&D and Equity Market Developments. J. Bank. Financ. 2009, 33, 971-984.

6. Brown, J.R.; Martinsson, G.; Petersen, B.C. Do Financing Constraints Matter for R\&D? Eur. Econ. Rev. 2012, 56, 1512-1529.

7. Amore, M.D.; Schneider, C.; Zaldokas, A. Credit Supply and Corporate Innovation. J. Financ. Econ. 2013, 109, 835-855. [CrossRef]

8. Sasaki, T. Financial Cash Flows and Research and Development Investment. Pac.-Basin Financ. J. 2016, 39, 1-15. [CrossRef]

9. Guariglia, A.; Liu, P. To What Extent Do Financing Constraints Affect Chinese Firm's Innovation Activities? Int. Rev. Financ. Anal. 2014, 36, 223-240. [CrossRef]

10. Howell, A. Firm R\&D, Innovation and Easing Financial Constraints in China: Does Corporate Tax Reform Matter? Res. Policy 2016, 45, 1996-2007.

11. Brown, J.R.; Petersen, B.C. Cash Holdings and R\&D Smoothing. J. Corp. Financ. 2011, 17, 694-709.

12. Bates, T.W.; Chang, C.H.; Chi, J.D. Why Has the Value of Cash Increased Over Time? J. Financ. Quant. Anal. 2018, 53, 749-787. [CrossRef]

13. Sasidharan, S.; Lukose, P.J.J.; Komera, S. Financing Constraints and Investments in R\&D: Evidence from Indian Manufacturing Firms. Q. Rev. Econ. Financ. 2015, 55, 28-39.

14. Arellano, M.; Bover, O. Another Look at The Instrumental-Variable Estimation of Error-Components Models. J. Econom. 1995, 68, 29-52. [CrossRef]

15. Blundell, R.; Bond, S. Initial Conditions and Moment Restrictions in Dynamic Panel Data Models. J. Econom. 1998, 87, 115-143. [CrossRef]

16. Dasgupta, S.; Noe, T.; Wang, Z. Where Did All the Dollars Go? The Effect of Cash Flows on Capital and Asset Structure. J. Financ. Quant. Anal. 2011, 46, 1259-1294. [CrossRef]

17. Kim, W.; Weisbach, M.S. Motivations for Public Equity Offers: An International Perspective. J. Financ. Econ. 2008, 87, 281-307. [CrossRef]

18. Bloom, N.; Griffith, R.; Reenen, J.V. Do R\&D Tax Credits Work? Evidence from a Panel of Countries 1979-1997. J. Public Econ. 2002, 85, 1-31.

19. Mukherjee, A.; Singh, M.; Zaldokas, A. Do Corporate Taxes Hinder Innovation? J. Financ. Econ. 2017, 124, 195-221. [CrossRef]

20. Girma, S.; Gong, Y.; Görg, H. Foreign Direct Investment, Access to Finance, and Innovation Activity in Chinese Firms. World Bank Econ. Rev. 2008, 22, 367-382. [CrossRef]

21. Li, J.; Chen, D.; Shapiro, D.M. Product Innovations in Emerging Economies: The Role of Foreign Knowledge Access Channels and Internal Efforts in Chinese Firms. Manag. Organ. Rev. 2010, 6, 243-266. [CrossRef]

22. Gompers, P.A. Optimal Investment, Monitoring, and the Staging of Venture Capital. J. Financ. 1995, 50, 1461-1489. [CrossRef]

23. Cochrane, J.H. The Risk and Return of Venture Capital. J. Financ. Econ. 2005, 75, 3-52. [CrossRef]

24. Borisova, G.; Brown, J.R. R\&D Sensitivity to Asset Sale Proceeds: New Evidence on Financing Constraints and Intangible Investment. J. Bank. Financ. 2013, 37, 159-173.

25. Ju, X.; Lo, D.; Yu, Y. Financing Constraints, Working Capital Management, and the Sustainability of Firm Innovation. Econ. Res. J. 2013, 48, 4-16. (In Chinese)

26. Allen, F.; Qian, J.; Qian, M. Law, Finance and Economic Growth in China. J. Financ. Econ. 2005, 77, $116-157$. [CrossRef]

27. Faccio, M.; Masulis, R.W.; McConnell, J.J. Political Connections and Corporate Bailouts. J. Financ. 2006, 61, 2597-2635. [CrossRef]

28. Khwaja, A.I.; Mian, A. Do Lenders Favor Politically Connected Firms? Rent Provision in an Emerging Financial Market. Q. J. Econ. 2005, 120, 1371-1411. [CrossRef]

29. Adhikari, A.; Derashid, C.; Zhang, H. Public Policy, Political Connections and Effective Tax Rates: Longitudinal Evidence from Malaysia. J. Account. Public Policy 2006, 25, 574-595. [CrossRef] 
30. Yu, X.Y.; Wang, H.X. How should the Center Lead China's reforestation Efforts? —Policy Making Games between Central and Local Governments. Resour. Conserv. Recycl. 2013, 80, 64-84. [CrossRef]

31. Fan, K.W. Central-Provincial Relations for Anti-Schistosomiasis Policy in China. Iran. J. Public Health 2012, 41, 1-11. [PubMed]

32. Li, J.; Chiang, Y.H.; Choy, L. Central-Local Conflict and Property Cycle: A Chinese Style. Habitat Int. 2011, 35, 126-132. [CrossRef]

33. Harhoff, D. Are There Financing constraints for R\&D and Investment in German Manufacturing Firms? Annales d' Economies et de Statistique 1998, 49-50, 421-456.

34. Nanda, R.; Nicholas, T. Did Bank Distress Stifle Innovation during the Great Depression? J. Financ. Econ. 2014, 114, 273-292. [CrossRef]

35. Bougheas, S.; Görg, H.; Strobl, E. Is R\&D Financially Constrained? Theory and Evidence from Irish Manufacturing. Rev. Ind. Organ. 2003, 22, 159-174.

36. Ham, J.C.; Reilly, K.T. Testing intertemporal substitution, implicit contracts, and hours restriction models of the labor market using micro data. Am. Econ. Rev. 2002, 92, 905-927. [CrossRef]

37. Su, F.B.; Tao, R.; Xi, L.; Li, M. Local Officials' Incentives and China's Economic Growth: Tournament Thesis Reexamined and Alternative Explanatory Framework. China Word Econ. 2012, 20, 1-18. [CrossRef]

38. Fan, J.P.H.; Titman, S.; Twite, G. An International Comparison of Capital Structure and Debt Maturity Choices. J. Financ. Quant. Anal. 2012, 47, 23-56. [CrossRef]

39. Lin, J.; Li, Z. Policy Burden, Privatization and Soft Budget Constraint. J. Comp. Econ. 2008, 36, 90-102. [CrossRef]

40. Brandt, L.; Li, H.B. Bank Discrimination in Transition Economies. J. Comp. Econ. 2003, 31, 387-413. [CrossRef]

41. Fazzari, S.M.; Hubbard, R.G.; Petersen, B.C. Financing Constraints and Corporate Investment; Brookings Papers on Economic Activity; Brookings Institution Press: Washington, DC, USA, 1988; pp. 141-206.

42. Cleary, S. The Relationship between Firm Investment and Financial Status. J. Financ. 1999, 54, 673-692. [CrossRef]

43. Kaplan, S.N.; Zingales, L. Do Investment Cash-Flow Sensitivities Provide Useful Measures of Financing Constraints? Q. J. Econ. 1997, 112, 169-215. [CrossRef]

44. Gomes, J.F. Financing Investment. Am. Econ. Rev. 2001, 91, 1263-1285. [CrossRef]

45. Erickson, T.; Whited, T.M. Measurement Error and the Relationship between Investment and q. J. Political Econ. 2000, 108, 1027-1057. [CrossRef]

46. Alti, A. How Sensitive Is Investment to Cash Flow When Financial is Frictionless? J. Financ. 2003, 58, 707-722. [CrossRef]

47. Bond, S.; Meghir, C. Dynamic Investment Models and the Firm's Financial Policy. Rev. Econ. Stud. 1994, 61, 197-222. [CrossRef]

48. Ratti, R.A.; Lee, S.; Seol, Y. Bank Concentration and Financial Constraints on Firm-Level Investment in Europe. J. Bank. Financ. 2008, 32, 2684-2694. [CrossRef]

49. Chan, K.S.; Dang, V.Q.T.; Yan, I.K.M. Financial reform and financing constraints: Some evidence from listed Chinese firms. China Econ. Rev. 2012, 23, 482-497. [CrossRef]

50. Lin, J.; Cai, F.; Li, Z. Competition, Policy Burdens, and State-Owned Enterprise Reform. Am. Econ. Rev. 1998, 88, 422-427.

51. Bai, J.; Lian, L. Why Do State-Owned Enterprises Over-Invest? Government Intervention or Managerial Entrenchment. China J. Account. Stud. 2013, 1, 236-259. [CrossRef]

52. Zhu, H.; Yoshikawa, T. Contingent Value of Director Identification: The Role of Government Directors in Monitoring and Resource Provision in An Emerging Economy. Strateg. Manag. J. 2016, 37, 1787-1807. [CrossRef]

53. Sun, J.H.; Chen, C.M. A Research on the Relation between Demographic Characteristics and the Formation of Entrepreneur Social Capital. Econ. Manag. 2011, 33, 107-1113. (In Chinese)

(C) 2018 by the authors. Licensee MDPI, Basel, Switzerland. This article is an open access article distributed under the terms and conditions of the Creative Commons Attribution (CC BY) license (http:/ / creativecommons.org/licenses/by/4.0/). 